\title{
Pengembangan Sensor Kesegaran Buah Pepaya Potong (Carica Papaya L.) Pada Kemasan Pintar Berbasis Indikator pH Alami Kunyit (Curcuma Longa L.)
}

\section{Development Of Cuts Papaya (Carica Papaya L.) Freshness Sensor On Smart Packaging Based On Turmeric's Natural pH Indicator}

\author{
${ }^{1}$ Venny Diah Ningsih, ${ }^{2}$ Siti Nurrosyidah \\ ${ }^{1,2}$ Program Studi S1 Farmasi, Fakultas Ilmu Kesehatan, Universitas Ibrahimy \\ ${ }^{1}$ Email: venny@ibrahimy.ac.id
}

\begin{abstract}
ABSTRAK
Buah pepaya potong mudah mengalami penurunan kualitas, sehingga dibutuhkan label pintar untuk mendeteksi kesegaran buah pepaya potong tersebut.Label pintar untuk mendeteksi kesegaran buah pepaya potong dibuat dengan mengimobilisasikan membran kertas saring whatmann pada indikator kunyit. Label pintar memiliki waktu respon 2 menit, reprodusibilitas yang baik ditunjukkan dengan nilai RSD $<5 \%$, serta waktu pakai sensor yaitu 15 hari. Label pintar telah berhasil diterapkan untuk mendeteksi kesegaran buah pepaya potong di pasaran.
\end{abstract}

Kata Kunci: kesegaran buah papaya potong, label pintar, pH, indicator kunyit

ABSTRACT

Papaya cut easily loses quality, so a smart label is needed to detect the freshness of the papaya cut. Smart label for detecting papaya freshness are made by immobilizing whatmann filter paper membrane on the indicator of turmeric. Smart label have a 2 minutes response time, good reproducibility is indicated by the RSD values $<5 \%$, and the usage time is 15 days. Smart label have been successfully applied to detect freshness of cut papayas on the market.

Keywords: freshness of cut papaya, smart label, pH, indicator of turmeric

\section{PENDAHULUAN}

Pepaya (Carica papaya. L) merupakan tanaman yang berasal dari daerah Amerika Tengah dan tersebar luas di Pasifik Selatan dan daerah tropis lainnya. Pepaya dapat tumbuh di daerah basah dan kering mulai dari dataran rendah maupun dataran tinggi, terutama di daerah tropis. Pepaya juga mengandung serat dan kadar air yang tinggi sehingga buah pepaya ini memiliki tingkat kebusukan yang lebih tinggi dibandingkan buah yang lain. Proses pembusukan pepaya akan meningkat bila disimpan pada suhu tinggi dan juga meningkatkan kontaminasi jamur. Hal ini juga akan berpengaruh terhadap perubahan $\mathrm{pH}$, dimana semakin tinggi suhu penyimpanan buah semangka maka akan menurunkan $\mathrm{pH}$ buah semangka tersebut (Rivan dan Suherman, 2020).

Kunyit (Curcuma longa Linn.) termasuk salah satu tanaman rempah dan 
obat, habitat asli tanaman ini meliputi wilayah Asia khususnya Asia Tenggara. Kunyit merupakan salah satu indikator kimia alami yang mengandung senyawa kurkumin. Sifat kurkumin yang menarik adalah perubahan warna akibat perubahan $\mathrm{pH}$ lingkungan. Dalam suasana asam kurkumin berwarna kuning atau kuning jingga sedangkan dalam suasana basa berwarna merah. Hal terrsebut dapat terjadi karena adanya sistem tautomeri pada molekulnya (Kusbiantoro dan Purwaningrum, 2018). Kemasan pintar merupakan sistem pengemasan yang didalamnya terdapat label pintar sehingga mampu menjalankan fungsi pintar (seperti penginderaan, pendeteksian, pelacakan, pencatatan, dan komunikasi) agar dapat mengetahui pengambilan keputusan untuk memperpanjang umur simpan, meningkatkan kualitas, meningkatkan keamanan, memberikan informasi, dan memberikan peringatan tentang adanya kemungkinan kesalahan (Otles dan Yalcin, 2008). Berdasarkan latar belakang di atas, maka perlu dikembangkan penelitian mengenai label pintar sebagai sensor kesegaran buah pepaya potong.

\section{METODE PENELITIAN}

Penelitian ini bersifat eksperimental laboratorik. Dalam penelitian ini tahapan yang dilakukan adalah (1) optimasi sensor yaitu waktu imobilisasi, (2) pembuatan sensor yang akan diimobilisasikan dengan indikator kunyit, (3) karakterisasi sensor meliputi waktu pakai, waktu respon, dan reprodusibilitas, (4) aplikasi sensor pada buah pepaya potong, dan (5) analisa perubahan warna pada sensor saat diaplikasikan pada buah pepaya potong menggunakan image.

Alat-alat yang digunakan adalah timbangan analitik OHAUS PA214, gelas ukur $10 \mathrm{~mL}$, pipet tetes, beaker glass, plat tetes, pinset, batang pengaduk, vial, indikator $\mathrm{pH}$ universal Merck, scanner, imageJ, lemari pendingin, kotak penyimpanan sensor, plastic klip, sarung tangan plastic, pisau, saringan, gunting, penggaris, cutter, sterofoam. Bahan yang digunakan dalam penelitian ini adalah aquades, kertas saring "whatmann" cat no 1001150, buah pepaya, kunyit.

Pengemasan buah pepaya potong menggunakan styrofoam lalu ditutup dengan plastic wrap. Pada plastic wrap tersebut telah diberi label pintar pada bagian dalamnya. Penutupan diusahakan 
rapi dan tidak ada celahudara dari luar yang masuk dalam kemasan.

\section{HASIL DAN PEMBAHASAN}

\section{Fabrikasi Sensor Kesegaran}

\section{Buah Pepaya Potong}

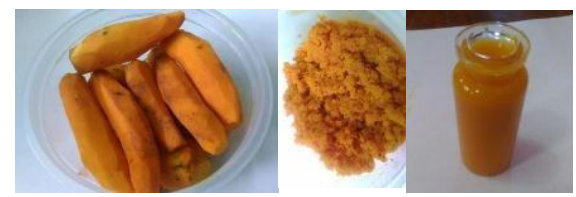

Gambar 1. Proses pembuatan indikator kunyit

$\begin{array}{rcr}\text { Pembuatan } & \text { indikator kunyit } \\ \text { diawali dengan ekstraksi kunyit. }\end{array}$ Ekstraksi kunyit dilakukan dengan cara mengupas kulit kunyit lalu menimbang kunyit sebanyak 50 gram, lalu diparut dan diambil sarinya. Sebanyak 50 gram kunyit menghasilkan kurang lebih $10 \mathrm{~mL}$ ekstrak.

Langkah selanjutnya yaitu menyiapkan membran yang telah dipotong berbentuk lingkaran dengan diameter $0,7 \mathrm{~cm}$ dan diimobilisasikan dalam indikator kunyit selama kurang lebih 10 menit. Kemudian setelah diimobilisasikan, membran diangkat digunakan untuk tahap selanjutnya.

\section{Optimasi waktu imobilisasi}

Waktu imobilisasi yang dipilih yaitu 2 - 12 menit. Berikut adalah hasil dari optimasi waktu imobilisasi yang dapat dilihat pada gambar 1 .

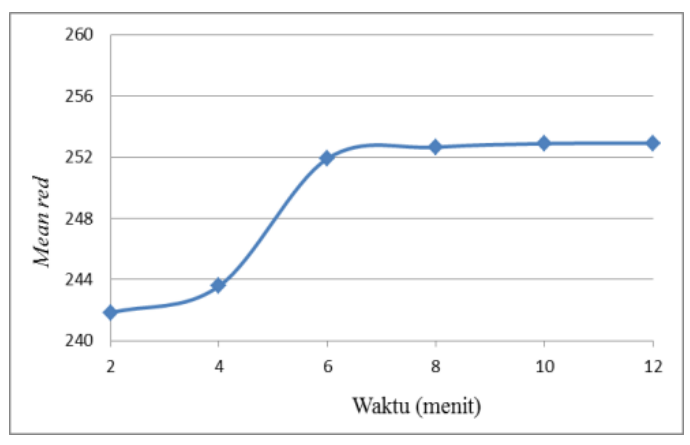

Gambar 2. Grafik hubungan antara mean red dengan waktu imobilisasi

Berdasarkan grafik di atas, hasil yang didapatkan menunjukkan bahwa pada waktu 8 menit nilai mean red steady-state yaitu 252.646, sehingga waktu imobilisasi yang digunakan untuk tahap selanjutnya yaitu 8 menit.

\section{Waktu respon}

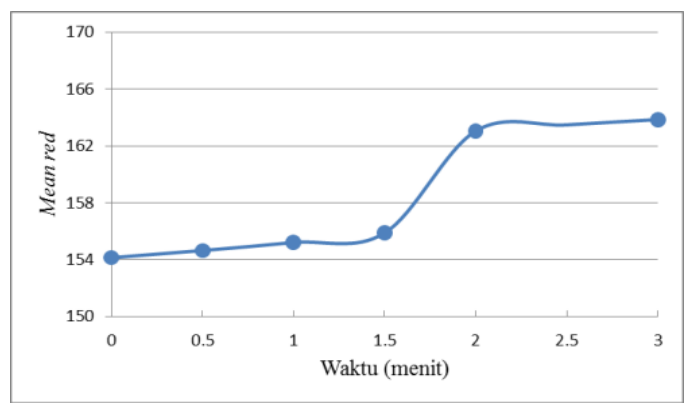

Gambar 3. Grafik hubungan antara waktu respon dan nilai mean red

Berdasarkan grafik di tas, Sensor yang direaksikan dengan larutan $\mathrm{pH} 6$ telah berubah warna dan steady-state pada menit ke-2 dengan nilai mean red 163,048 yang menandakan bahwa sensor telah bereaksi secara sempurna dan memberikan respon yang stabil. 


\section{Waktu pakai}

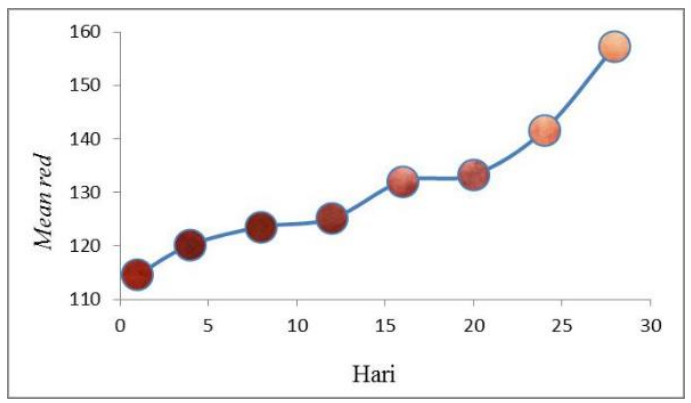

Gambar 4. Hubungan antara waktu (hari) dan nilai mean red

Tabel 1. Hubungan antara waktu dan nilai mean red

\begin{tabular}{cccc} 
Hari & $\begin{array}{c}\text { Kenaikan } \\
\text { mean red }\end{array}$ & Hari & $\begin{array}{c}\text { Kenaikan } \\
\text { mean red }\end{array}$ \\
\hline 1 & $0 \%$ & 10 & $8.653 \%$ \\
2 & $0,376 \%$ & 11 & $8.852 \%$ \\
3 & $2.816 \%$ & 12 & $9.131 \%$ \\
4 & $4.862 \%$ & 13 & $10.541 \%$ \\
5 & $5.129 \%$ & 14 & $13.318 \%$ \\
6 & $5.932 \%$ & 15 & $13.437 \%$ \\
7 & $7.435 \%$ & 16 & $14.931 \%$ \\
8 & $7.493 \%$ & 17 & $15.066 \%$ \\
9 & $7.902 \%$ & 18 & $15.632 \%$ \\
\hline
\end{tabular}

Pada gambar 4 menunjukkan perubahan warna sensor saat diaplikasikan pada larutan $\mathrm{pH} \quad 6$ sedangkan pada tabel 1 menunjukkan \% kenaikan mean red. Sensor masih stabil sampai hari ke-15 dengan persentase kenaikan nilai mean red yaitu sebesar $13,437 \%$ sehingga masih memenuhi syarat yaitu tidak lebih dari $15 \%$ (Kuswandi, 2010).

\section{Reprodusibilitas}

Tabel 2. Nilai RSD Mean red

\begin{tabular}{ccc}
\hline Hari & Mean & \%RSD \\
\hline 1 & 254.388 & $1.287 \%$ \\
2 & 256.721 & $0.546 \%$ \\
3 & 256.388 & $0.346 \%$ \\
\hline
\end{tabular}

Berdasarkan tabel 2, reprodusibilitas berdasarkan nilai RSD dari mean red memenuhi persyaratan yaitu $<5 \%$ (Kuswandi, 2010).

\section{Intensitas Perubahan Warna Sensor saat Diaplikasikan Pada Buah Pepaya Potong}

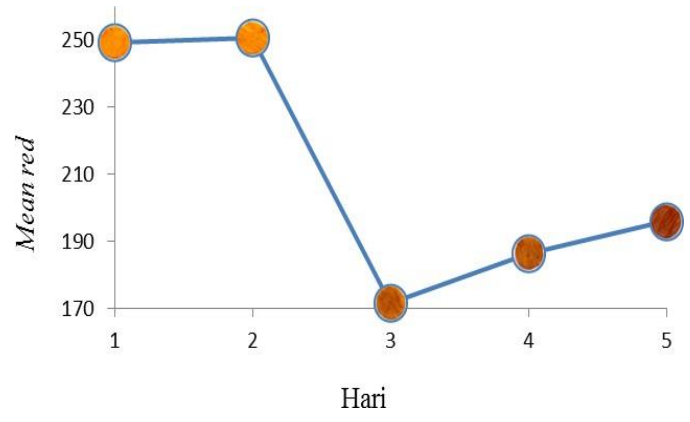

Gambar 5. Hubungan antara hari dengan nilai mean red

Berdasarkan gambar 5, menunjukkan perubahan warna sensor secara visual. Pada hari pertama sensor berwarna kuning dan pada hari kedua berangsur sedikit cerah. Pada hari ketiga sensor berubah menjadi warna coklat muda dan pada hari keempat dan kelima berangsur menjadi coklat muda yang lebih cerah (lebih pudar). Saat sensor berubah warna, disaat itulah buah pepaya 
potong telah megalami pembusukan.

\section{SIMPULAN DAN SARAN}

Berdasarkan hasil penelitian yang telah dilakukan, dapat diambil kesimpulan waktu imobilisasi sensor yang optimum yaitu 8 menit. Karakterisasi sensor untuk mendeteksi kesegaran pada buah ada 3, yaitu waktu respon sensor saat diaplikasikan pada buah yaitu 2 menit, waktu pakai sensor yaitu 15 hari, dan reprodusibilitas berdasarkan intensitas warna atau nilai mean red menunjukkan bahwa perubahan warna dengan 3 kali replikasi selama 3 hari memiliki RSD < 5\% sehingga dapat dikatakan bahwa sensor memiliki keterulangan yang baik.

Saran dalam penelitian ini yaitu perlu pengembangan sensor kesegaran buah pepaya potong dengan membran yang dapat dimakan (edible) sehingga sensor dapat bersentuhan langsung dengan sampel dan bisa dimakan.

\section{DAFTAR PUSTAKA}

Kusbiantoro, D., Y. Purwaningrum. 2018. Pemanfaatan kandungan metabolit sekunder pada tanaman kunyit dalam mendukung peningkatan pendapatan masyarakat Utilization of secondary metabolite in the turmeric plant to increase community income. 17(1), 544-549

Kuswandi, B. 2010. Sensor Kimia: Teori, Praktek \& Aplikasi. Jember: UPT Penerbitan Universitas Jember.

Otles, S. dan B. Yalcin. 2008. LogForum. 4:1-9. Intelligent Food Packaging

Rivan dan Suherman. 2020. Penentuan Mutu Buah Pepaya California (Carica Papaya L.) Menggunakan Fuzzy Mamdani. 12:76-83 